\title{
Toxicon
}

Toxicon 48 (2006) 55-63

www.elsevier.com/locate/toxicon

\section{Toxicity and toxin identification in Colomesus asellus, an Amazonian (Brazil) freshwater puffer fish}

\author{
Joacir Stolarz Oliveira ${ }^{\mathrm{a}, *}$, Solange Cristina Rego Fernandes ${ }^{\mathrm{b}}$, Carlos \\ Alberto Schwartz ${ }^{b}$, Carlos Bloch Jr. ${ }^{\mathrm{c}}$, Jorge Alex Taquita Melo ${ }^{\mathrm{c}}$, \\ Osmindo Rodrigues Pires Jr. , José Carlos de Freitas ${ }^{\mathrm{a}}$ \\ ${ }^{a}$ Department of Physiology, Biosciences Institute, University of São Paulo. Rua do Matão 101, Travessa 14, 05508900 São Paulo, Brazil \\ ${ }^{\mathrm{b}}$ Toxinology Laboratory, Department of Physiological Sciences, Biology Institute, University of Brasilia, Brasilia, DF 70910900, Brazil \\ ${ }^{\mathrm{c}}$ Mass Spectrometry Laboratory, EMBRAPA-CENARGEN, P.O. BOX 02372, Brasilia, DF, Brazil
}

Received 15 February 2006; received in revised form 20 April 2006; accepted 24 April 2006

Available online 3 May 2006

\begin{abstract}
Toxicity and toxin identification in Colomesus asellus, an Amazonian (Brazil) freshwater puffer fish. By using four different techniques - mouse bioassay, ELISA, HPLC and mass spectrometry - we evaluated the toxicity in the extracts of C. asellus, a freshwater puffer fish from the rivers of the Amazon, and identified for the first time the components responsible for its toxicity. The T20G10 monoclonal antibody raised against TTX, and employed in an indirect competitive enzyme immunoassay, showed very low affinity for the $C$. asellus extracts, indicating that TTX and its analogs are not the main toxic components of the extracts. This antibody was efficient in detecting presence of TTX in a total extract of Sphoeroides spengleri, which is one of the most toxic puffer fish found in the Atlantic coast. Extracts of $C$. asellus were toxic when administered intraperitonially into mice with an average toxicity of $38.6 \pm 12$ mouse unit (MU)/g, while HPLC analysis indicated a lower toxin content $(7.6 \pm 05 \mathrm{MU} / \mathrm{g})$. The HPLC profile showed no traces of TTX, but only the presence of PSPs (STX, GTX 2 and GTX 3). These toxins were also confirmed by electrospray ionization mass spectrometry.
\end{abstract}

(C) 2006 Elsevier Ltd. All rights reserved.

Keywords: Colomesus asellus; Sphoeroides spengleri; ELISA; Freshwater puffer fish; Saxitoxin; Gonyautoxin; HPLC; Mass spectrometry

\section{Introduction}

Puffer fishes are poisonous and may cause a characteristic clinical poisoning with a high mortality rate, but in Japan and China, have long been a delicacy (Lange, 1990). In Occidental countries, puffer fishes are only sporadically consumed and

\footnotetext{
*Corresponding author. Fax: + 551130917568

E-mail address: jstolarz@usp.br (J.S. Oliveira).
}

have been involved in several human poisonings, mainly by the species belonging to the genus Sphoeroides (Almeida and Rocha, 1989; Ochoa et al., 1997; MMWR, 2002). Toxinological studies of some Sphoeroides species have been reported (Correa et al., 1990; Freitas et al., 2003; Oliveira et al., 2003).

The poison of freshwater puffers may be composed by tetrodotoxin (TTX) or saxitoxin (STX) and its analogs, the predominant toxin being 
dependent on the species. These guanidinium toxins inhibit electrical signaling in many excitable cells (nerves and muscles) by binding to the site 1 , blocking the pore of the voltage-gated sodium channels (VGSC) (Cestèle and Catterall, 2000).

The correct identification whether which toxin, TTX or STX, is the main toxic component of a determined puffer poison is not always a simple task. For example, Tetraodon fangi, the Thailand freshwater puffer involved in some food poisonings in humans (Saitanu et al., 1991), was first reported to posses mainly TTX as its poison (Laobhripatr et al., 1990). Later, however, the major toxins of this fish were identified as STXs (Sato et al., 1997). Furthermore, other freshwater puffers such as Tetraodon leiurus complex and Tetraodon suvatii from Thailand and Tetraodon cutcutia and Chelonodon patoca from Bangladesh may posses many paralytic shellfish poisoning (PSP) toxins (such as STX, neo-STX, decarbamoyl-STX, GTX 2, GTX 3, and decarbamoyl-GTX 2 and 3) (Kungsuwan et al., 1997; Zaman et al., 1997).

Nowadays, at least 185 species of puffer fishes in the family Tetraodontidae, distributed in 28 genera are known. In the genus Colomesus there are only two species described (Fishbase, 2005). Both species occur in Brazil: Colomesus asellus (Amazon puffer) is an exclusively freshwater puffer living in the Amazon basin, and Colomesus psittacus (banded puffer) inhabits brackish waters at the Brazilian northeast coast estuaries. C. psittacus was reported to possess an edible flesh and a very toxic liver (Sawaya, 1966), but the toxins and toxicity of C. asellus are as yet completely unknown.

In this work, by using four different techniques (mouse bioassay, ELISA, HPLC and mass spectrometry), we report for the first time the high toxicity found in C. asellus and the identification of PSPs (STX and gonyautoxins) as the main components of its poison.

\section{Material and methods}

\subsection{Extraction}

Twenty-four specimens of C. asellus (Müller and Troschel, 1848) were collected from the River Tocantins, in the town harbor of Cametá, Pará State, Brazil, in March of 2003. The total length of animals (in $\mathrm{cm}$ ) and body weight (in grams) varied from 9 to 15.6 and from 18 to 96 , respectively. The extraction procedure was according to Oliveira et al. (2003) with slight modifications. Briefly, six separated extracts were prepared from total body of $C$. asellus as described below (for the number of specimens used and weights, see Table 1).

Extracts were prepared by double extraction with $1 \%$ acid acetic in $70 \%$ ethanol $(2 \mathrm{ml} / \mathrm{g})$, filtered,

Table 1

Toxicity of Colomesus asellus extracts (MU means mouse unit) evaluated by different techniques

\begin{tabular}{|c|c|c|c|c|c|c|c|}
\hline \multirow[t]{3}{*}{ Sample } & \multirow{3}{*}{$\begin{array}{l}\text { Number of } \\
\text { specimens }\end{array}$} & \multirow{3}{*}{$\begin{array}{l}\text { Average body } \\
\text { weight }(\mathrm{g})\end{array}$} & \multicolumn{4}{|l|}{ Toxicity } & \multirow[t]{3}{*}{ ELISA $^{\mathrm{a}}$} \\
\hline & & & \multicolumn{2}{|c|}{ Mouse bioassay } & \multicolumn{2}{|l|}{ HPLC } & \\
\hline & & & $\mathrm{MU} / \mathrm{g}$ & MU/indiv & $\mathrm{MU} / \mathrm{g}$ & MU/indiv & \\
\hline 1 & 4 & 172.00 & 53.2 & 2287.5 & 17.74 & 764.5 & 0.0045 \\
\hline 2 & 4 & 162.60 & 31.2 & 1268.3 & 4.99 & 202.8 & 0.0057 \\
\hline 3 & 3 & 82.60 & 46.0 & 1267.5 & 10.18 & 280.3 & 0.0022 \\
\hline 4 & 6 & 176.80 & 44.0 & 1296.7 & 5.35 & 157.6 & 0.0032 \\
\hline 5 & 3 & 212.20 & 37.8 & 2675.0 & 4.36 & 308.4 & 0.0027 \\
\hline \multirow[t]{2}{*}{6} & 4 & 121.50 & 19.4 & 590.20 & 3.23 & 98.1 & 0.0064 \\
\hline & & & $38.60 \pm 12.01$ & $1564.20 \pm 768.49$ & $7.64 \pm 5.49$ & $301.95 \pm 239.45$ & $0.0041 \pm 0.0017$ \\
\hline $\begin{array}{l}\text { Positive } \\
\text { control }^{\mathrm{b}}\end{array}$ & 285 & 10.92 & 45.53 & nd & nd & nd & 93.77 \\
\hline
\end{tabular}

Six independent total body extracts of C. asellus were analyzed by mouse bioassay, high-performance liquid chromatography (HPLC) and enzyme-linked immunosorbent assay (ELISA), and the toxicity expressed as mouse unit per gram of fresh tissue (MU/g) or per mean of body weight from one specimen individually (MU/indiv). A total body extract of several specimens of Sphoeroides spengleri was employed as positive control.

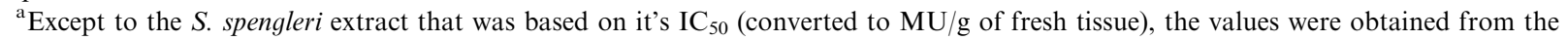
highest concentration of each extract.

${ }^{\mathrm{b}}$ Extract of Sphoeroides spengleri (positive control); nd, not determined. 
defatted with $80 \%$ methylene chloride, vacuum concentrated, and ressuspended with distilled water to a known concentration.

\subsection{Toxicity assay}

The toxicity of $C$. asellus extracts was initially determined in accordance with the method of Kawabata (1978). After performing preliminary analysis by high performance liquid chromatography (HPLC), it was found that the toxic compounds were PSPs and, in addition, a mouse bioassay according to the AOAC method was carried out (Williams, 1984).

\subsection{ELISA assay}

In order to verify the possible presence of TTX in the extracts of C. asellus we carried out an enzymelinked immunosorbent assay (ELISA) using a monoclonal antibody raised against TTX (MAbTTX). The assay was according to Raybould et al. (1992).

\subsection{Preparation of a conjugate-coat antigen}

A conjugate-coating antigen (BSA-TTXF) was prepared by mixing bovine serum albumin $(89.5 \mu 1$ of BSA at $33.6 \mathrm{mg} / \mathrm{ml})$, TTX $(350 \mu \mathrm{l}$ at $1 \mathrm{mg} / \mathrm{ml})$ and formaldehyde $(20.5 \mu \mathrm{l}$ of a $37 \%$ solution, added drop wise). The reaction mixture was incubated under shaking at $37^{\circ} \mathrm{C}$ for 3 days, and subsequently dialyzed against four changes (of $1 \mathrm{~L}$ ) of $50 \mathrm{mM}$ sodium phosphate, $\mathrm{pH} 7.0$, containing $150 \mathrm{mM}$ $\mathrm{NaCl}$ (PBS) at $4{ }^{\circ} \mathrm{C}$. The conjugate concentration was determined spectrophotometrically using an extinction coefficient at $280 \mathrm{~nm}$ of $0.667 \mathrm{mg} . \mathrm{cm} / \mathrm{ml}$.

\subsection{Indirect competitive inhibition enzyme immunoassay (ICEIA) for TTX}

An immulon microtiter plate (Dynatech Laboratories Inc., Chantilly, VA) was coated with $100 \mu \mathrm{l} /$ well of BSA-TTXF at a concentration of $5 \mu \mathrm{g} / \mathrm{ml}$ in PBS, and kept under incubation at $4{ }^{\circ} \mathrm{C}$ overnight. This plate was then washed three times with PBS containing $0.05 \% \quad(\mathrm{v} / \mathrm{v})$ tween-20 (PBS-T) and blocked with $200 \mu \mathrm{l} /$ well of blocker solution (PBSB: $0.5 \%$ gelatine $(\mathrm{w} / \mathrm{v})+0.2 \%$ tween $(\mathrm{v} / \mathrm{v})$ in PBS) for $2 \mathrm{~h}$ at room temperature. Separately, plastic tubes were filled with $75 \mu \mathrm{l}$ of each sample: (a) serial dilutions from the highest concentrations of each extract of C. asellus; (b) TTX standard curve as a control; and (c) an extract from Sphoeroides spengleri, a marine puffer fish that possesses high amounts of TTX (Oliveira et al., 2003), employed as a positive control extract for the presence of TTX. These samples were challenged with $75 \mu \mathrm{g} / \mathrm{ml}$ of Mab-TTX (final fixed concentration per tube for all experiments $=100 \mathrm{ng} / \mathrm{ml}$ ); the highest standard TTX concentration used was $2.5 \mu \mathrm{g} / \mathrm{ml}$. After $2 \mathrm{~h}$ incubation the contents of the tubes $(100 \mu l)$ were transferred to the previously blocked plate. This plate was incubated at room temperature for $1 \mathrm{~h}$ and then washed three times with PBS-T. Peroxidase-rabbit anti-mouse IgG $(\mathrm{H}+\mathrm{L})$, diluted in PBS was added, and after incubation for $1 \mathrm{~h}$ at room temperature, the plate was again washed out and $100 \mu 1$ of ABTS added, followed by a new incubation for $15 \mathrm{~min}$. The reaction was stopped with $25 \mu 1$ hydrofluoric acid $(50 \%, \mathrm{v} / \mathrm{v})$ and the absorbance at $405 \mathrm{~nm}$ measured in a microtiter plate reader Spectra MAX 250 (Molecular Devices, CA, USA). Six independent experiments, in duplicate, were performed for all samples. Fifty percent inhibitory concentration $\left(\mathrm{IC}_{50}\right)$ and values from TTX standard curve, expressed in $\mu \mathrm{g} / \mathrm{ml}$, were used to establish the sensitivity of the method and to estimate the different toxin concentrations.

Monoclonal antibody T20G10 against TTX (MAb-TTX) was from Hawaii Biotechnology Group, Hawaii. Peroxidase-rabbit anti-mouse IgG $(\mathrm{H}+\mathrm{L})$ was from Zymed, USA, 2,2'-azino-di (3-ethylbenzothiazoline-6-sulfonate) (ABTS) from Boehringer Mannheim, Germany and hydrofluoric acid from Sigma, USA.

\subsection{References toxins}

Tetrodotoxin was obtained from Sankyo Co., Japan. Saxitoxin was obtained from US Food and Drug Administration, USA, and Gonyautoxins were a kind gift from Dr. Takehiko Ogata, Kitasato University, Japan.

\subsection{Purification of STX and analogs}

The toxic extracts were partially purified by ionexchange chromatography using an Amberlite GC$50 \mathrm{NH}_{4}^{+}(1.0 \times 6.0 \mathrm{~cm})$ column. The retained material was eluted with $10 \%$ acetic acid, vacuum concentrated, and submitted to treatment with active charcoal (Norit-A). The adsorbed toxins were eluted with $1 \%$ acetic acid in $20 \%$ ethanol 
(Goto et al., 1965), and the solvent subsequently evaporated to dryness at $65^{\circ} \mathrm{C}$. The dried material was diluted in milli-Q water, filtered in a $0.22 \mu \mathrm{m}$ membrane and further submitted to HPLC.

\subsection{HPLC-FLD analysis}

TTXs were detected by HPLC carried out on a Shimadzu LC-10A HPLC system according to Pires et al. (2002). A Shimpack $C_{18}$ column $(4.6 \times 250 \mathrm{~mm}$ i.d., Shimadzu Corp., Japan) was used with a mobile phase of $60 \mathrm{mM}$ heptanesulfonic acid and $10 \mathrm{mM}$ ammonium phosphate buffer ( $\mathrm{pH}$ 5.0). The eluate from the column was continuously mixed with an equal volume of $4 \mathrm{M} \mathrm{NaOH}$ and heated in a reaction coil at $110^{\circ} \mathrm{C}$. The toxin was detected with a fluorescence detector, monitoring the fluorescence at $500 \mathrm{~nm}$ with $380 \mathrm{~nm}$ excitation.

PSP analysis was carried out in the same HPLC system, as described previously (Oshima, 1995). A Synergy-Fusion $\mathrm{C}_{18} \quad$ Phenomenex column $(4.6 \times 150 \mathrm{~mm}$ i.d., GenTech Scientific Inc., NY, USA) was used in combination with the two mobile phases: (I) $2 \mathrm{mM}$ heptanesulfonic acid in $10 \mathrm{mM}$ ammonium phosphate buffer $(\mathrm{pH}$ 7.1) for gonyautoxins (GTXs), and (II) $2 \mathrm{mM}$ heptanesulfonic acid with $3 \%$ acetonitrile, in $30 \mathrm{mM}$ ammonium phosphate buffer ( $\mathrm{pH}$ 7.1) for STXs. The eluate from the column was continuously mixed with $7 \mathrm{mM}$ periodic

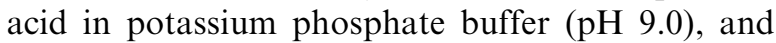
heated at $85^{\circ} \mathrm{C}$. The fluorophors formed were monitored at $390 \mathrm{~nm}$ with a $330 \mathrm{~nm}$ excitation.

\subsection{Mass spectrometry analysis}

Aliquots of the C. asellus extracts were analyzed by electrospray ionization in a Q-TOF Ultima API (Waters, Manchester, UK), operating in positive $\mathrm{W}$ mode. The sample was applied at a flow rate of $2 \mu \mathrm{l} / \mathrm{min}$ in a solvent mixture consisting of water/ methanol/acetic acid (50:50:0.1). The capillary and cone voltages were set to $2.8 \mathrm{kV}$ and $30 \mathrm{~V}$, respectively.

\section{Results and discussion}

C. asellus is an Amazonian freshwater puffer fish that occasionally is sold by the aquarists. Apart from the popular knowledge that it is poisonous, this species is completely unknown to science, as there have been no studies concerning its biology, behavior, ecology and toxicity.
In this study, the toxicity of $C$. asellus extracts was initially evaluated by mouse bioassay. When injected into mice (i.p.) the toxicities varied from 19.4 to 53.2 mouse unit (MU)/g, as shown in Table 1. It has been reported that freshwater puffer fishes from rivers in Thailand may contain less than $50 \mathrm{MU} / \mathrm{g}$ in their tissues, as observed for $T$. fangi and Tetraodon palembangensis (Saitanu et al., 1991). On the other hand, species containing higher amounts of toxins are not rare. T. leiurus may exhibit toxicities varying from 35 to $750 \mathrm{MU} / \mathrm{g}$ depending on the source tissue, the ovary being the most toxic (Kodama and Ogata, 1984). Furthermore, likewise marine puffers, the toxicity of freshwater puffers may vary according to the location and the season in which the fish is caught (Kungsuwan et al., 1997). Here we present results only from total body extracts and, therefore, further studies will be necessary to evaluate the possible seasonality of the toxicity and the distribution of toxins in the tissues of $C$. asellus.

Since the toxin composition of the genus Colomesus is completely unknown, we performed the indirect competitive inhibition enzyme immunoassay (ICEIA) and HPLC analysis for TTXs, suspecting that the $C$. asellus could accumulate this toxin and its derivatives. Following this, analyses for PSPs were also performed.

The T20G10 MAb-TTX was employed in the ICEIA to detect TTX in the C. asellus whole body extracts. Competitive inhibition curves were obtained from a standard curve of TTX, an extract from $S$. spengleri, jointly with 6 extracts of $C$. asellus, as shown in Fig. 1(A and B). Linear regression of the standard curve was obtained, giving a correlation coefficient of 0.99339 . These results demonstrated very high sensitivity that was confirmed by the lowest detection limit of TTX as close to $0.1 \mathrm{ng} / \mathrm{ml}(\sim 0.00041 \mathrm{MU})$.

The highest concentration of the $C$. asellus extracts employed in the ICEIA, $15 \mathrm{mg} / \mathrm{ml}$, was not able to completely inhibit the binding of all the content of MAb-TTX to the plate coated with BSAF-TTX. Based on this feature and since the highest concentration of standard TTX was only $2.5 \mu \mathrm{g} / \mathrm{ml}$ we could make, by this assay, only a rough estimation of the toxicity of the $C$. asellus extracts, expressing it as $\mathrm{MU} / \mathrm{g}$ of fresh tissue (Table 1). For this, we used the highest concentration of each extract obtained from the partial curves (shown in Fig. 1), and the values did not represent the real toxicity in the extracts. 

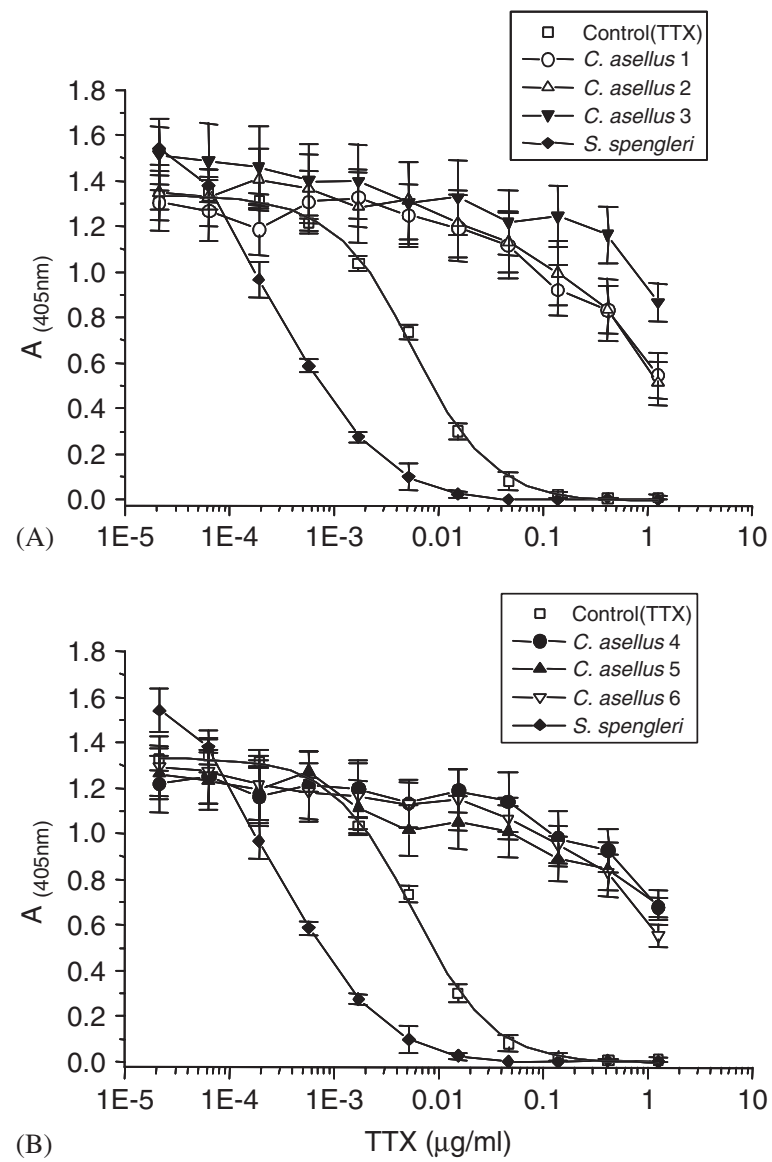

Fig. 1. Indirect CEIA using Mab-TTX T20G10 for the detection of TTX in puffer fish extracts. Six total extracts (1-3, A and 4-6, B) of C. asellus, diluted in PBS and a total extract of various $S$. spengleri specimens were compared with a TTX standard curve. The curves of TTX and S. spengleri are the same in (A) and (B); extracts from C. asellus were separated only to clear the visualization. $\mathrm{IC}_{50}$ of TTX and $S$. spengleri were 5.0 and $0.2 \mathrm{ng} / \mathrm{ml}$, respectively. Vertical bars indicate the mean \pm standard error of mean of six independent experiments, in duplicate.

The toxins in $C$. asellus extracts showed very low affinity in binding to the MAb-TTX, demonstrating that TTX is not the main toxic compound in these fishes. On the other hand, the $S$. spengleri extract, employed as a positive control, was able to completely inhibit the MAb-TTX binding to the BSATTX, resulting in an $\mathrm{IC}_{50}$ of $0.2 \mathrm{ng} / \mathrm{ml}$. The toxicity curve of this extract shifted leftward, showing that this extract contains, at least, $125 \mathrm{ng} / \mathrm{ml}$ of TTX, which is 25 -fold more than the TTX standard solution $(5 \mathrm{ng} / \mathrm{ml})$. This result could also suggest a possible cross-reaction with other TTX derivatives present in the $S$. spengleri extract. Raybould et al. (1992) reported that, despite the high specificity, the
T2010 Mab-TTX might cross-react with other TTX analogs such as tetrodonic acid (TDA) and 4,9-anhydrotetrodotoxin (4,9-anhydroTTX), when these compounds are in high concentrations $\left(\mathrm{IC}_{50}>\right.$ $300 \mathrm{ng} / \mathrm{ml})$. We reported that, besides TDA and 4,9-anhydroTTX, S. spengleri also contains 4-epiTTX (Oliveira et al., 2003), a compound not yet investigated in this aspect. As will be discussed later, using other techniques we were able to confirm that $C$. asellus does not contain TTX and its derivatives.

Many different ELISA methods based on monoclonal antibodies have been developed to detect TTX, diarrheic (dinophysistoxin-1 and okadaic acid) and PSP (STXs and GTXs) toxins (Chu and Fan, 1985; Núnez and Scoging, 1997; Kawatsu et al., 2002). These may be employed by local authorities to easily evaluate the toxicity of large numbers of samples. Our ELISA results confirmed the high specificity of the T20G10 against TTX, which enabled us to speculate that the crossreaction of the $C$. asellus extracts, even in low levels, with MAb-TTX may be attributed to the high concentrations used in these assays.

The identification of STX and its derivatives in the $C$. asellus extracts was achieved by HPLC comparison of their retention time with that of the standard compounds. The HPLC-FLD analysis showed the presence of high quantities of STX, (Fig. 2(A and B)), and only traces of GTX 2 and GTX 3 (Fig. 2(C and D)). It has been reported that some species of puffer fishes may accumulate both STX and TTX, and sometimes only the association of more than one chemical technique, such as HPLC and mass spectrometry, may accurately discriminate these two toxins (Nakashima et al., 2004). In the case of $C$. asellus, there was no evidence for TTX and its derivatives by both HPLC and mass spectrometry (Data not shown). Therefore, our results clearly demonstrated that STX is the main toxic component in $C$. asellus. We also have determined that the STX-equivalent in all extracts was higher in the bioassay than the HPLCFLD analysis. This might be due either to a synergistic effect with other PSPs that might contribute to the total toxicity observed in the mouse bioassay or to a partial recovery of the toxins in the HPLC analysis.

Considering the origin of the toxins, it is well known that puffer fishes do not produce TTX and their derivatives, instead the production is caused by various species of bacteria living in a symbiotic 

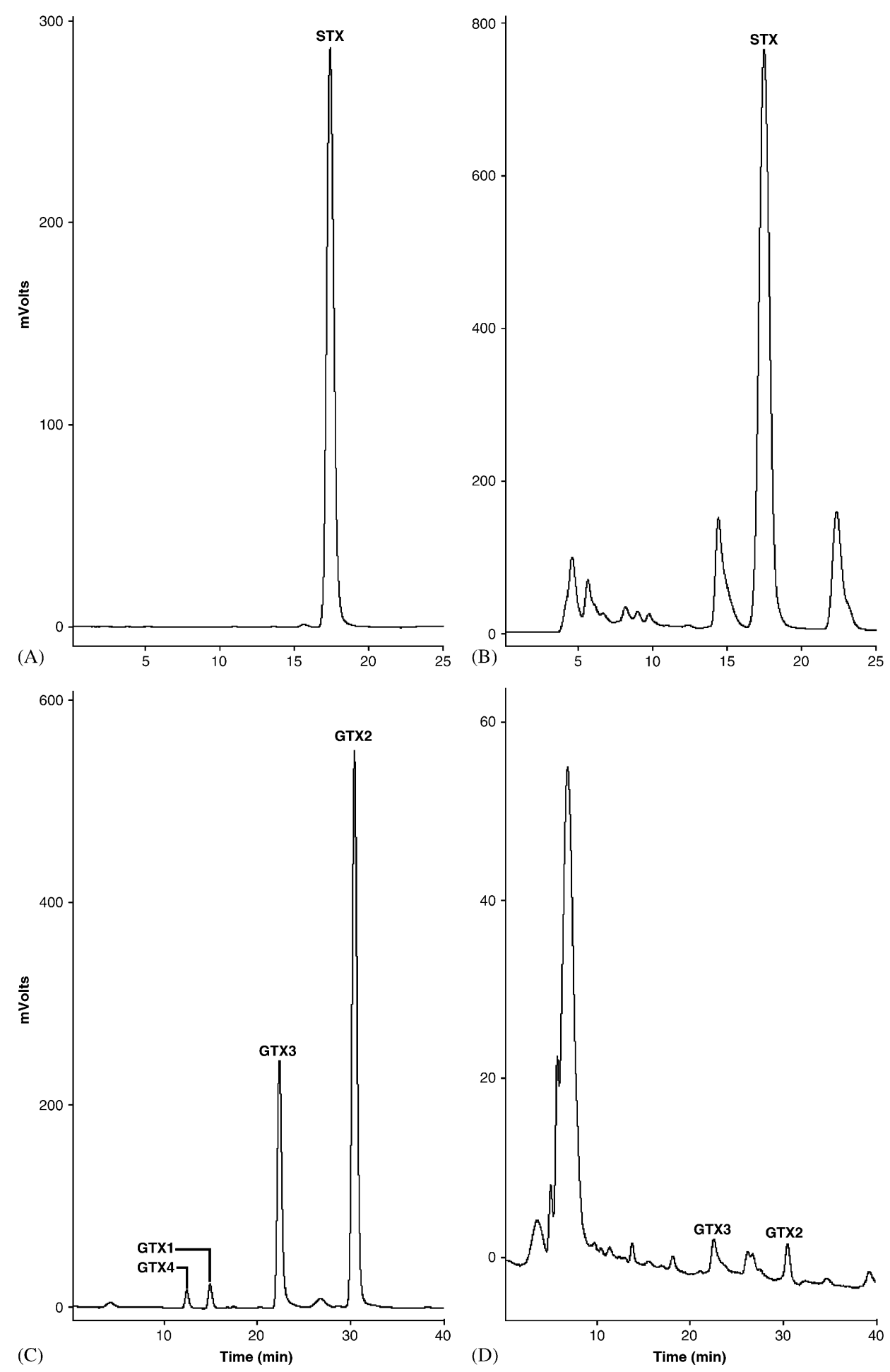

Fig. 2. Chromatogram profile in HPLC-FLD system of the standard toxins STX (A) and GTX 1-4 (C), and Colomesus asellus extract (B and D). Peak: saxitoxin (STX) and (GTX) gonyautoxin. 
association with these fishes (Yotsu et al., 1987; Noguchi et al., 1987) or they are acquired through the food chain (Yasumoto and Yotsu-Yamashita, 1996). In the marine environment, STXs, which cause PSP, are produced by some species of dinoflagellates from the genus Alexandrium (Gonyaulax) (Schantz, 1986). It is also known that some xanthid crabs, horseshoe crabs and marine snails may posses PSP toxins, not associated with dinoflagellates (Sato et al., 1997). In freshwaters, certain species of cyanobacteria are involved in the production of these toxins (Lagos et al., 1999). Although we did not investigate the possible bacterial source of toxins present in $C$. asellus tissues, this cannot be ruled out, based on the fact that $C$. asellus is an exclusively freshwater puffer.
The presence of saxitoxin in the C. asellus extracts was confirmed by mass spectroscopy (Fig. 3). The spectrum showed the similar fragmentation pattern from $m / z 300.2860(\mathrm{M}+\mathrm{H})^{+}$to those obtained by Fang et al. (2004) and Sleno et al. (2005). The daughter ions at $m / z 282.1862,240.0042,196.1669$, $182.7655,161.8719$ were consistent with the structures suggested by Sleno et al. (2005).

In conclusion, $C$. asellus, like other freshwater puffer fishes, accumulates saxitoxin, although no NeoSTX was present in our samples. In Brazil, some marine puffers are sporadically consumed by the local population (Oliveira et al., 2003), and poisoning cases were reported (Almeida and Rocha, 1989). In spite of there being no reports of food poisonings or even consumption of freshwater

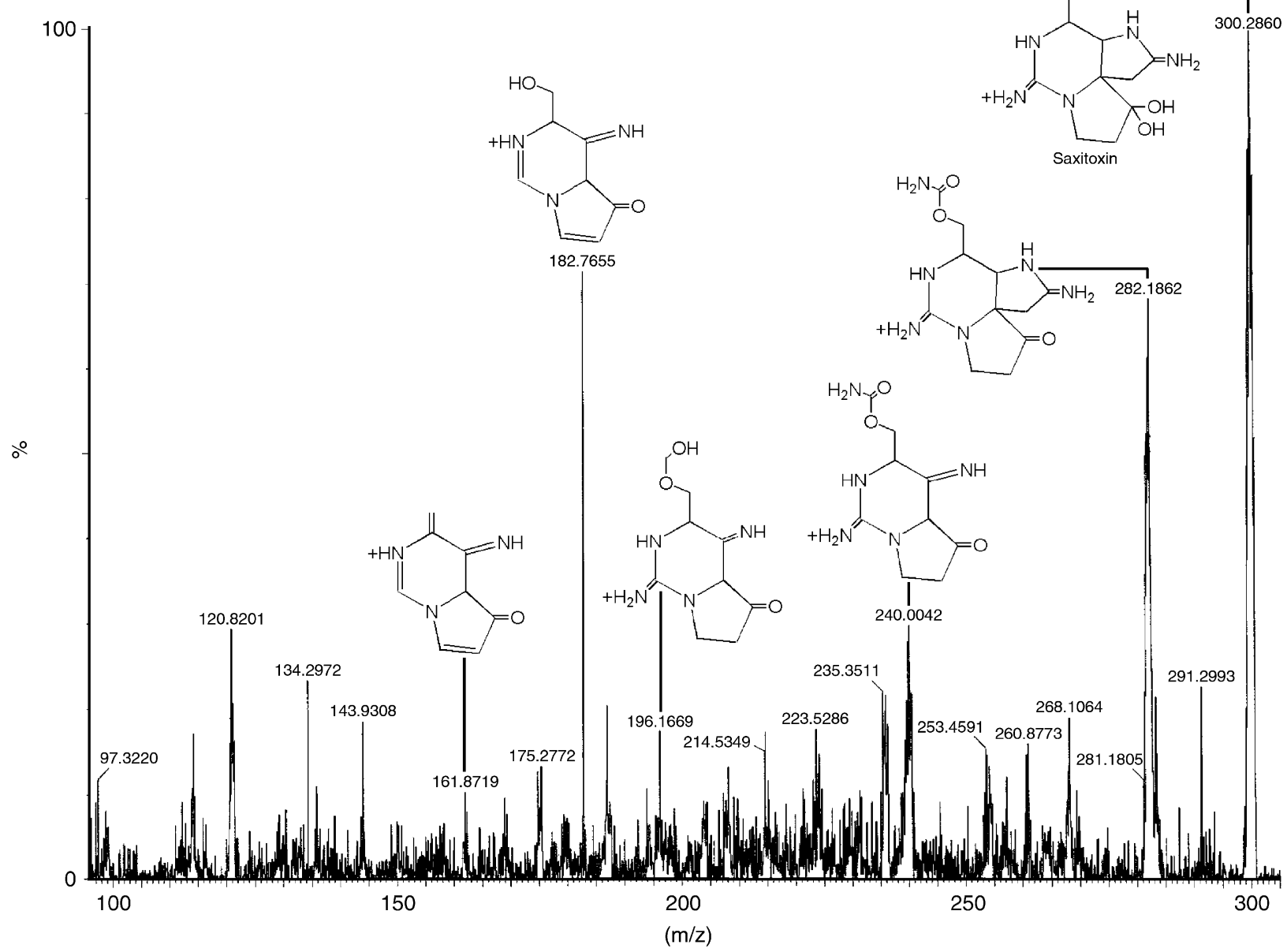

Fig. 3. Fragmentation ion profile of mass component in $300.2860(\mathrm{M}+\mathrm{H})^{+}$from the C. asellus extracts, showing a fragmentation pattern similar to STX obtained by Fang et al. (2004) and Sleno et al. (2005). 
puffers by people in the Amazon region, we strongly recommend that the consumption of the Brazilian puffer C. asellus should be avoided.

\section{Acknowledgements}

We are profoundly indebted to Prof. Dr. Takehiko Ogata of the Kitasato University, Japan, for providing us with Gonyautoxins. We also thank Mr. Vagner Alberto of the Biosciences Institute at USP for his technical assistance. Thanks to Drs. André J. Zaharenko of the Biosciences Institute at USP, Katsuhiro Konno of the Centro de Toxinologia Aplicada - CAT/ CEPID-FAPESP and Michael Richardson of the Fundação Ezequiel Dias-FUNED for the suggestions and critical reading of the manuscript. This research was supported by FAPESP, CAPES and CNPq.

\section{References}

Almeida, V.G., Rocha, C.M., 1989. Registers of accidents with venomous and/or poisonous fishes. Rev. Soc. Bras. Toxicol. 2, 49-51 (in Portuguese).

Cestèle, S., Catterall, W.A., 2000. Molecular mechanisms of neurotoxin action on voltage-gated sodium channels. Biochimie 82, 883-892.

Chu, F.S., Fan, T.S., 1985. Indirect enzyme-linked immunosorbent assay for saxitoxin in shellfish. J. Assoc. Off. Anal. Chem. 68, 13-16.

Correa, M.F., Silva, L.R., Konolsaisen, J.F., Assanuma, M.H., Abilhoa, V., 1990. Oral toxicity of chekered puffer fish Sphoeroides testudineus (Osteichthyes-Tetraodontiformes) on mice and sintomatology of intoxication on mice (Mus musculus) and Guinea pigs (Cavia porcelus) (in Portuguese). Arq. Biol. Tecnol. 33, 413-438.

Fang, X., Fan, X., Tang, Y., Chen, J., Lu, J., 2004. Liquid chromatography/quadrupole time-of-flight mass spectrometry for determination of saxitoxin and decarbamoylsaxitoxin in shellfish. J. Chromatogr. A 1036 (2), 233-237.

FishBase, 2005. Froese, R. and D. Pauly., editors. World Wide Web electronic publication. www.fishbase.org, version (11/ 2005).

Freitas, J.C., Rangel, M., Oliveira, J.S., Zaharenko, A.J., Rozas, E., 2003. An outline on marine toxinology studies in the Brazilian coast. Comment. Toxicol. 9, 1-22.

Goto, T., Kishi, Y., Takahashi, S., Hirata, Y., 1965. Tetrodotoxin. Tetrahedron 21 (8), 2059-2088.

Kawabata, T., 1978. Tetrodotoxin. In: The Manual for the Methods of Food Sanitation Tests, vol. II. Bureau of Environmental Health Ministry of Health and Welfare, Food Hygiene Association, Tokyo, Japan, p. 232.

Kawatsu, K., Hamano, Y., Sugiyama, A., Hashizume, K., Noguchi, T., 2002. Development and application of an enzyme immunoassay based on a monoclonal antibody against gonyautoxin components of paralytic shellfish poisoning toxins. J. Food Protect. 65, 1304-1308.
Kodama, M., Ogata, T., 1984. Toxicity of a freshwater puffer Tetraodon leiurus. Bull. Jpn. Soc. Sci. Fish. 50, 1949-1951.

Kungsuwan, A., Arakawa, O., Promdet, M., Onoue, Y., 1997. Occurrence of paralytic shellfish poisons in Thai freshwater puffers. Toxicon 35 (8), 1341-1346.

Lagos, N., Onodera, H., Zagatto, P.A., Andrinolo, D., Azevedo, S.M.F.Q., Oshima, Y., 1999. The first evidence of parallytic shellfish toxins in the freshwater cyanobacterium Cylindrospermospsis raciborskii, isolated from Brazil. Toxicon 37, 1359-1373.

Lange, W.R., 1990. Puffer fish poisoning. Am. Fam. Phys. 42, 1029-1033.

Laobhripatr, S., Limpakarnjanarat, K., Sangwonloy, O., Sudhasaneya, S., Anuchatvorakul, B., Leelasitorn, S., Saitanu, K., 1990. Food poisoning due to consumption of the freshwater puffer Tetraodon fangi in Thailand. Toxicon 28 (11), 1372-1375.

MMWR, 2002. Update: neurologic illness associated with eating Florida pufferfish, 2002. MMWR 51 (19), 414-416.

Nakashima, K., Arakawa, O., Taniyama, S., Nonaka, M., Takatani, T., Yamamori, K., Fuchi, Y., Noguchi, T., 2004. Occurrence of saxitoxins as a major toxin in the ovary of a marine puffer Arothron firmamentum. Toxicon 43, 207-212.

Noguchi, T., Hwang, D.F., Arakawa, O., Sugita, H., Deguchi, Y., Shida, Y., Hashimoto, K., 1987. Vibrio alginolyticus, a tetrodotoxin-producing bacterium in the intestines of the fish Fugu vermicularis vermicularis. Mar. Biol. 94, 625-630.

Núnez, P.E., Scoging, A.C., 1997. Comparison of a protein phosphatase inhibition assay, HPLC assay and enzyme-linked immunosorbent assay with the mouse bioassay for the detection of diarrhetic shellfish poisoning toxins in European shellfish. Int. J. Food Microbiol. 36, 39-48.

Ochoa, J.L., Sánchez-Paz, A., Cruz-Villacorta, A., NuñezVázquez, E., Sierra-Beltrán, A., 1997. Toxic events in the northwest Pacific coastline of Mexico during 1992-1995: origin and impact. Hydrobiología 352, 195-200.

Oliveira, J.S., Pires, Jr., O.R., Morales, R.A.V., Bloch Junior, C., Schwartz, C.A., Freitas, J.C., 2003. Toxicity of puffer fishtwo species (Lagocephalus laevigatus, Linaeus 1766 and Sphoeroides spengleri, Bloch 1785) From the Southeastern Brazilian Coast. J. Venom. Anim. Toxins 9, 76-88.

Oshima, Y., 1995. Postcolumn derivatization liquid-chromatographic method for paralytic shellfish toxins. J. A.O.A.C. Int. 78 (2), 528-532.

Pires Jr., O.R., Sebben, A., Schwartz, E.N.F., Largura, S.W.R., Bloch Jr., C., Morales, R.A.V., Schwartz, C.A., 2002. Occurrence of tetrodotoxin and its analogues in the Brazilian frog Brachycephalus ephippium (Anura: Brachycephalidae). Toxicon 40, 761-766.

Raybould, T.J.G., Bignami, G.S., Inouye, L.K., Simpson, S.B., Byrnes, J.B., Grothaus, P.G., Vann, D.C., 1992. A monoclonal antibody-based immunoassay for detecting tetrodotoxin in biological samples. J. Clin. Lab. Anal. 6, 65-72.

Saitanu, K., Laobhripath, S., Limpakarnjanarat, K., Sangwanloy, O., Sudhasaneya, S., Anuchatvorakul, B., Leelasitorn, S., 1991. Toxicity of the freshwater puffer fish Tetraodon fangi and T. palembangensis from Thailand. Toxicon 29, 895-897.

Sato, S., Kodama, M., Ogata, T., Saitanu, K., Furuya, M., Hirayama, K., Kakinuma, K., 1997. Saxitoxin as a toxic principle of a freshwater puffer, Tetraodon fangi, in Thailand. Toxicon 35 (1), 137-140. 
Sawaya, P., 1966. Toxic marine invertebrates - venomous and noxious fishes of freshwater. Mem. Inst. Butantan 33, 31-34.

Schantz, E.J., 1986. Chemistry and biology of saxitoxin and related toxins. Ann. N.Y. Acad. Sci. 479, 13-23.

Sleno, L., Volmer, D.A., Marshall, A.G., 2005. Assigning product ions from complex MS/MS spectra: the importance of mass uncertainty and resolving power. J. Am. Soc. Mass Spectrom. 16 (2), 183-198.

Williams, S., 1984. Paralytic shellfish poison. In: Official Methods of Analysis of the A.O.A.C., 14th ed. Association of Official Analytical Chemists, Arlington, VA, USA, pp. 344-345.
Yasumoto, T., Yotsu-Yamashita, M., 1996. Chemical and etiological studies on tetrodotoxin and its analogs. J. Toxicol.-Toxin Rev. 15, 81-90.

Yotsu, M., Yamazaki, T., Meguro, Y., Endo, A., Murata, M., Naoki, H., Yasumoto, T., 1987. Production of tetrodotoxin and its derivatives by Pseudomonas sp. isolated from the skin of a pufferfish. Toxicon 25, 225-228.

Zaman, L., Arakawa, O., Shimosu, A., Onoue, Y., 1997. Occurrence of paralytic shellfish poison in Bangladeshi freshwater puffers. Toxicon 35 (3), 423-431. 